\title{
HUBUNGAN TINGKAT PENGETAHUAN DAN MOTIVASI PERAWAT DENGAN TINGKAT KEPATUHAN DAN KETEPATAN DALAM MELAKUKAN FIVE MOMENT HAND HYGINE
}

\author{
Ebenezer Sitorus, Dewi Prabawati* \\ STIK Sint Carolus \\ Email:deprab24@yahoo.com
}

\begin{tabular}{ll}
\hline \multirow{4}{*}{$\begin{array}{l}\text { Keywords: } \\
\text { Knowledge, } \\
\text { Motivation, } \\
\text { Compliance, } \\
\text { Accuracy, }\end{array}$} & $\begin{array}{l}\text { Nurse compliance in performing hand hygiene brings essential impact } \\
\text { Five the health of nurses and patients, especially in preventing nosocomial } \\
\text { infections. Nosocomial infection cause negative effect on cost and length } \\
\text { of stay of patients. This study aimed to determine relationship between } \\
\text { level of knowledge and motivation towards level of compliance and } \\
\text { accuracy in performing Five Moments Hand Hygiene at inpatient } \\
\text { department Tzu Chi Hospital, Jakarta. This study uses a quantitative } \\
\text { descriptive correlation design method by distributing questionnaires and } \\
\text { filling observations tools. There were 40 nurses chosen as respondent } \\
\text { using simple random sampling technique. The results revealed that } \\
\text { majority of respondents have high level of knowledge (57.5\%), good } \\
\text { motivation (60\%), and compliance in performing five moments hand } \\
\text { hygiene (62.5\%) yet have less accuracy in performing hand hygiene } \\
\text { (62.5\%). Using statistical test of Kendall tau B, it was revealed that there } \\
\text { was a significant relationship between level of knowledge (p=0.001) and } \\
\text { motivation (p=0,042) with nurse compliance in performing five moments } \\
\text { hand hygiene; Moreover, there was significant relationship between level } \\
\text { of knowledge (p=0,011) with nurse accuracy in performing hand hygiene } \\
\text { procedures; however there was no significant relationship between } \\
\text { motivation with nurse accuracy in performing hand hygiene procedures } \\
\text { (p=0.042). It is suggested that hospital management strengthen } \\
\text { socialization, re-and demonstration or conduct hand hygiene competition. } \\
\text { In addition, enhancing hospital facilities is needed to improve nurse } \\
\text { behavior on five moments hand hygiene with intention to prevent } \\
\text { transmission of microorganisms that will cause nosocomial infections. }\end{array}$ \\
\hline
\end{tabular}

\section{PENDAHULUAN}

Dalam menjaga mutu pelayanan yang terstandar, rumah sakit mempunyai tangggung jawab terhadap pencegahan infeksi nosokomial. Infeksi nosokomial atau sering disebut Healthcare Associated Infection (HAI) terjadi pada pasien yang dalam masa perawatan. Infeksi nosokomial menimbulkan dampak negatif pada lamanya masa rawat, ketidakberdayaan dan dampak ekonomi baik pada pasien, keluarga bahkan tenaga kesehatan (Khan et al., 2017). Infeksi nosokomial bisa terjadi dari pasien ke pasien lain, dari pasien ke pengunjung atau keluarga, atau dari petugas ke pasien saat melaksanakan tindakan atau perawatan pasien. Center for 
Disease (CDC) mengklasifikasikan penularan infeksi melalui 4 kategori yaitu vena sentral (aliran darah); kateter; luka pembedahan dan ventilator (Sikora, A., Zahra, 2021).

Kejadian infeksi nosokomial di rumah sakit dunia mencapai $9 \%$ atau kurang lebih 1,4 juta pasien yang rawat inap, dan sekitar $8,7 \%$ dari 55 rumah sakit dari 14 negara yang berasal dari Eropa, Timur Tengah, dan Pasifik menunjukkan adanya infeksi nosokomial di rumah sakit. Angka kejadian infeksi nosokomial di rumah sakit di negara-negara Asia sekitar 3-21\% (rata-rata 9\%) (Soedarto, 2016).

Pencegahan infeksi nosokomial salah satunya dapat dilakukan dengan cara melakukan five moments hand hygiene. Hal ini didukung dengan penelitian dari Mera et al. (2018) yang menemukan bahwa terdapat hubungan yang significant antara penerapan five moments hand hygiene dan cuci tangan 6 langkah dengan kejadian infeksi nosocomial di rumah sakit $(\mathrm{p}<0.05)$. Pencegahan melalui pengendalin infeksi nosocomial di rumah sakit ini mutlak dilakukan oleh profesi kesehatan dan seluruh jajaran menejemen rumah sakit dalam memberikan pelayanan kesehatan bagi pasien, yang meliputi tenaga dokter, perawat, bidan dan tenaga kesehatan lain.

World Health Organization (2009) mencetuskan tantangan keselamatan pasien secara global dengan semboyan "clean care is safe care”, yaitu dengan melakukan My Five Moment For Hand Hygiene yaitu tindakan cuci tangan sebelum bersentuhan dengan pasien, sebelum melakukan prosedur bersih dan steril, setelah bersentuhan dengan cairan tubuh pasien, setelah bersentuhan dengan pasien, setelah bersentuhan dengan lingkungan sekitar pasien. Hal ini bertujuan agar dapat mengontrol penyebaran pathogen dan, mencegah infeksi silang,

Namun, masih banyak tenaga kesehatan yang kurang menyadari pentingnya melakukan hand hygiene sesuai dengan prosedur. Susilo (2015) menemukan bahwa petugas kesehatan di RS X Surabaya belum dapat dikatakan patuh dalam kegiatan hand hygiene, dimana langkah menggunakan handuk untuk menutup kran air dan melakukan prosedur dalam 40-60 detik sama sekali tidak dilakukan $(0 \%)$. Penelitian lain menemukan bahwa sebagian besar perawat memiliki motivasi lemah dalam melakukan hand hygiene (Sani \& Pratiwi, 2017).

Lebih lanjut dijelaskan bahwa petugas kesehatan masih rendah dalam melakukan 5 moments hand hygine, terutama moment saat sebelum kontak dengan pasien (9,5\%), sebelum tindakan antisepsis (0\%), sesudah terkena cairan tubuh pasien (23\%), dan sesudah kontak dengan area sekitar pasien (9,5\%) (Susilo, 2015). Penelitian lain disalah satu rumah sakit swasta menemukan tingginya angka infeksi nosokomial diruang rawat inap sebesar 8,16\%; sedangkan angka kepatuhan dalam melakukan cuci tangan perawat sebelum menyentuh pasien masih rendah 
sebesar $50 \%$ dan setelah menyentuh pasien 80\% (Setiawan, 2016).

Tenaga kesehatan yang paling rentan dalam penularan infeksi nosokomial adalah perawat, karena tingginya waktu interaksi dan pendampingan dengan pasien. Dalam hal ini, perawat memberikan kontribusi yang signifikan dalam pencegahan infeksi nosokomial. Kepatuhan hand hygiene itu sendiri dipengaruhi oleh banyak faktor, diantaranya pengetahuan dan motivasi (Gea et al., 2018). Lebih lanjut dijelaskan responden yang memiliki pengetahuan baik akan memiliki kepatuhan yang baik dalam melakukan hand hygiene, dan didapatkan hubungan yang signifikant antara pengetahuan perawat tentang pencegahan infeksi nosocomial dengan kepatuhan mencuci tangan $(\mathrm{p}<0.05)$.

Survey pendahuluan yang dilakukan di Rumah Sakit Cinta Kasih Tzu Chi mulai bulan Juli - Desember 2018, dari 132 orang perawat terdapat $75,8 \%$ perawat yang melakukan tindakan five moment hand hygiene dengan cukup baik, sedangkan target di rumah sakit adalah $80 \%$. Pihak rumah sakit sendiri telah melakukan upaya meningkatkan pengetahuan perawat melalui melakukan pelatihan pada perawat baru dan sosialisasi serta dilakukan simulasi bagi perawat senior. Target yang belum tercapai ini membuat peneliti tertarik untuk mengetahui adanya hubungan tingkat pengetahuan dan motivasi perawat dengan tingkat kepatuhan dan ketepatan dalam melakukan five moments hand hygiene di ruang rawat inap rumah sakit

\section{METODE}

Penelitian ini menggunakan desain deskriptif korelasi dengan cara menyebarkan kuesioner dan mengisi lembar observasi. Sampel dalam penelitian ini dipilih secara simple random sampling, dan terdapat 40 perawat yang bekerja di ruang perawatan Rawat Inap Rumah Sakit Cinta Kasih Tzu Chi, Cengkareng, Jakarta Barat sebagai responden.

Instrument menggunakan kuesioner yang disusun berdasarkan literature terkait dan telah melalui uji reabilitas dan validitas. Kuesioner pengetahuan terdiri dari 20 pertanyaan dengan Cronbach's Alpha 0,958 dan $\mathrm{r}$ table 0.38; Hasil ukur pengetahuan dibagi menjadi 3 hasil ukur yaitu: baik (76\%$100 \%)$, cukup (56\%-75), dan kurang (<56\%). Kuesioner motivasi terdiri dari 20 pertanyaan dengan Cronbach's Alpha 0,977 dan r tabel 0,38 . Hasil ukur motivasi terbagi 2 hasil ukur yaitu: baik (60-100\%) dan kurang baik $(<60 \%)$. Untuk kepatuhan five moments hand hygiene dan ketepatan melakukan prosedur hand hygiene dilakukan pengamatan atau observasi selama 5 hari dengan menggunakan instrument sesuai SOP rumah sakit tempat melakukan penelitian.

Penelitian ini telah mendapat persetujuan dari Komite Etik STIK Sint Carolus No. 064/KEPPKSTIKSC/XII/2019. Analisa statistik menggunakan Kendall's Tau B untuk melihat hubungan antara variable. 


\section{HASIL}

Tabel 1. Frekuensi distribusi responden

\begin{tabular}{llll}
\hline \multirow{2}{*}{ Variabel } & Karakteristik & \multicolumn{2}{c}{ Jumlah } \\
\hline \multirow{2}{*}{ Usia } & & $\mathrm{n}$ & $\%$ \\
\cline { 3 - 4 } & 20-25 tahun & 14 & 35 \\
& 26-30 tahun & 14 & 35 \\
& 31-35 tahun & 8 & 20 \\
& 36-40 tahun & 2 & 5 \\
& $>40$ tahun & 2 & 5 \\
\hline Jenis kelamin & Laki-laki & 8 & 20 \\
& Perempuan & 32 & 80 \\
\hline Lama kerja & $<1$ tahun & 1 & 2.5 \\
& 1-2 tahun & 12 & 30 \\
& 3-4 tahun & 12 & 30 \\
& 5-6 tahun & 5 & 12.5 \\
& $>7$ tahun & 10 & 25 \\
\hline Tingkat & Baik & 23 & 57.5 \\
Pengetahuan & Cukup & 16 & 40 \\
& Kurang & 1 & 2.5 \\
\hline Motivasi & Baik & 24 & 60 \\
& Kurang & 16 & 40 \\
\hline Tingkat & Patuh & 25 & 62.5 \\
Kepatuhan & Tidak patuh & 15 & 37.5 \\
\hline Ketepatan & Tepat & 15 & 37.5 \\
& Tidak Tepat & 25 & 62.5 \\
\hline
\end{tabular}

Dari table 1 dapat dijelaskan bahwa dari 40 orang responden, paling banyak berusia antara 20-25 tahun dan 26-30 tahun sebanyak 35\%; berjenis kelamin perempuan $80 \%$, lama kerja antara 1-2 tahun dan 3-4 tahun sebanyak 30\%. Dari segi tingkat pengetahuan perawat tentang five moments hand hygiene mayoritas memiliki pengetahuan baik $(57.5 \%)$, memiliki motivasi baik (60\%), patuh dalam melakukan prosedur five moments hand hygiene $(62.5 \%)$ namun tidak tepat dalam melakukan prosedur hand hygiene ( $62.5 \%)$.

Tabel 2. Tingkat Kepatuhan perawat melakukan five moments hand hygiene

\begin{tabular}{lc}
\multicolumn{1}{c}{ Moment } & $(\boldsymbol{\%})$ \\
\hline Sebelum Kontak dengan Pasien & $72,5 \%$ \\
Sebelum melakukan tindakan Aseptik/ & $87,5 \%$ \\
Invasif & \\
Setelah terkena tubuh Pasien & $90 \%$ \\
Setelah kontak dengan Pasien & $85 \%$ \\
Setelah Kontak dengan Lingkungan & $92,5 \%$ \\
sekitar pasien & \\
\hline
\end{tabular}

Tabel 3. Tingkat ketepatan perawat dalam melakukan prosedur hand hygiene

\begin{tabular}{lc}
\hline \multicolumn{1}{c}{ Prosedur } & $\%$ \\
\hline Buka Kran air lalu basahi kedua tangan & $100 \%$ \\
Tuang sabun, ratakan sabun pada telapak tangan & $100 \%$ \\
Matikan Air dengan lengan bawah & $60 \%$ \\
Gosok kedua telapak tangan & $97,5 \%$ \\
Gosok punggung tangan dan sela-sela jari & $82,5 \%$ \\
Gosokkan sela-sela jari dengan cara kedua telapak & $80 \%$ \\
tangan berhadapan & $77,5 \%$ \\
Jari- jari dalam saling mengunci & $77,5 \%$ \\
Gosok ibu jari kiri memutar & $90 \%$ \\
Gosokkan ujung jari memutar pada telapak tangan & $72,5 \%$ \\
Buka Kran dan bilas kedua tangan dengan air & $57,5 \%$ \\
Tutup Kran kembali dengan lengan bawah & $92,5 \%$ \\
Keringkan tangan dengan Tissu & $100 \%$ \\
Buang Tissu ke tempat sampah non infeksius &
\end{tabular}

Tabel 2 memperlihatkan tingkat kepatuhan perawat dalam melakukan prosedur five moments hand hygiene yang diobservasi selama 5 hari pengamatan. Terlihat belum ada moment yang dilakukan $100 \%$ oleh perawat, dan moment sebelum kontak dengan pasien memiliki kepatuhan terendah diantara moment yang lain (72\%). Selain dilakukan observasi prosedur 5 moments, dilakukan pula observasi ketepatan perawat dalam melakukan langkah-langkah hand hygine disetiap moment seperti yang ditujukkan dalam tabel 3 . Sebagian besar perawat tepat dalam melakukan langkah-langkah hand hygine, namun prosedur mematikan dan menutup kran air dengan lengan bawah masih rendah $(<60 \%)$ diantara prosedur yang lain. 
Tabel 4. Hubungan Tingkat Pengetahuan dan motivasi dengan Tingkat Kepatuhan Perawat dalam melakukan five moments hand hygiene

\begin{tabular}{ccccccccc}
\hline & \multicolumn{4}{c}{ Tingkat Kepatuhan } & \multicolumn{2}{c}{ Total } & \multirow{2}{*}{ p } \\
\cline { 2 - 6 } Variabel & \multicolumn{3}{c}{ Patuh } & \multicolumn{2}{c}{ Tidak } & & & \\
\cline { 2 - 6 } & (n) & $\%$ & (n) & $\%$ & (n) & $\%$ & \\
\hline Pengetahuan & & & & & & & \\
\hline Baik & 19 & 47,5 & 4 & 10 & 23 & 57,5 & \\
Cukup & 6 & 15 & 10 & 25 & 16 & 40 & 0,001 \\
Kurang & 0 & 0 & 1 & 2,5 & 1 & 2,5 & \\
\hline Motivasi & & & & & & & \\
\hline Baik & 18 & 45 & 6 & 15 & 24 & 60 & 0.042 \\
Kurang & 7 & 17.5 & 9 & 22.5 & 16 & 40 & \\
\hline Tabel & & & & & & & &
\end{tabular}

Tabel 4 menunjukkan bahwa mayoritas responden dengan pengetahuan baik memiliki tingkat kepatuhan patuh dalam melakukukan five moments hand hygiene. (47.5\%), lebih tinggi dibandingkan dengan responden yang memiliki pengetahuan cukup (15\%). Hasil $p$ value 0.001 menyimpulkan ada hubungan signifikan antara pengetahuan dengan kepatuhan melakukukan five moments hand hygiene. Demikian halnya dengan motivasi, responden dengan motivasi baik memiliki tingkat kepatuhan patuh dalam melakukukan five moments hand hygiene. (45\%) lebih besar dibandingkan yang memiliki motivasi kurang (17.5). Berdasarkan $p$ value 0.042 disimpulkan bahwa terdapat hubungan signifikan antara motivasi dengan kepatuhan melakukukan five moments hand hygiene.

Tabel 5. Hubungan Tingkat Pengetahuan dan motivasi dengan Tingkat Ketepatan Perawat dalam melakukan prosedur Hand hygiene

\begin{tabular}{ccccccccc} 
& \multicolumn{3}{c}{ Tingkat Ketepatan } & \multicolumn{3}{c}{ Total } & \multirow{2}{*}{ p } \\
\cline { 2 - 6 } Variabel & \multicolumn{3}{c}{ Tepat } & \multicolumn{3}{c}{ Tidak } & & \\
\cline { 2 - 6 } & $(\mathbf{n})$ & $\%$ & $(\mathbf{n})$ & $\%$ & $(\mathbf{n})$ & $\%$ & \\
\hline Pengetahuan & & & & & & & \\
\hline Baik & 12 & 30 & 11 & 27.5 & 23 & 57.5 & \\
Cukup & 3 & 7.5 & 13 & 32.5 & 16 & 40 & 0.011 \\
Kurang & 0 & 0 & 1 & 2.5 & 1 & 2.5 & \\
\hline Motivasi & & & & & & & \\
\hline Baik & 11 & 27.5 & 13 & 32.5 & 24 & 60 & \multirow{2}{*}{0.162} \\
Kurang & 4 & 10 & 12 & 30 & 16 & 40 & \\
\hline
\end{tabular}

Tabel 5 menunjukkan bahwa mayoritas responden dengan pengetahuan baik memiliki tingkat ketepatan tepat dalam melakukukan prosedur hand hygiene (30\%), dimana nilai ini lebih tinggi dibandingkan dengan responden yang memiliki pengetahuan cukup (7.5\%). Terdapat hubungan signifikan antara pengetahuan dengan ketepatan perawat dalam melakukan prosedur hand hygiene ( $p$ value 0.011). Sedangkan untuk motivasi, responden dengan motivasi baik, mayoritas memiliki ketepatan dalam melakukan prosedur hand hygiene (27.5) demikian pula dengan yang memiliki motivasi kurang (10\%). Berdasarkan hasil statistic didapatkan $p$ value 0.162 yang berarti tidak ada hubungan signifikan antara motivasi dengan ketepatan perawat dalam melakukan prosedur hand hygiene.

\section{PEMBAHASAN}

Tingkat pengetahuan sangat erat hubungannya dengan pendidikan dan pengalaman seseorang, dimana seorang perawat dengan pendidikan yang tinggi dan ditunjang dengan pengalaman kerja yang baik akan menjadikan perawat tersebut memahami aspek kognitif dari suatu objek. Dalam penelitian ini, perawat yang bekerja di RSCK $>1$ tahun akan sering terpapar dengan sosialisasi tentang five moments hand hygiene yang dilakukan secara regular oleh pihak managemen rumah sakit.

Sosialisasi dan tindakan edukasi yang telah dilakukan secara berkala tentang five moments hand hygiene menjadikan mayoritas 
pengetahuan perawat tinggi. Hal ini sejalan dengan penelitian Listiowati \& Nilamsari (2015) yang menyatakan bahwa tingkat kepatuhan melaksanakan hand hygiene menalami peningkaatan $13.83 \%$ setelah diberikan simulasi hand hygiene; dan adanya hasil significant sebelum dan sesudah pemberian simulasi hand hygiene ( $p$ value $<0.05)$.

Motivasi seseorang dalam melakukan hand hygiene juga memiliki peran yang sangat penting. Hal ini dikarenakan motivasi yang tinggi akan memberikan kontribusi pada tingkat komitmen seseorang dalam melakukan kepatuhan five moments hand hygiene, yang dampaknya akan mengurangi risiko infeksi. Hasil penelitian ini sejalan dengan penelitian dari Sani \& Pratiwi (2017) yang menyatakan adanya hubungan antara motivasi perawat rawat inap dengan tingkat kepatuhan dalam melakukan 6 langkah cuci tangan yang benar dengan $p$ value 0.000 .

Dalam penelitian ini, motivasi perawat mayoritas baik, dimana motivasi dapat berasal dari factor intrinsic dan ekstrinsik. Dari hasil kuesioner juga digambarkan bahwa adanya pengaruh variable intrinsic seperti tanggung jawab, pengakuan, prestasi kerja, pengembangan karir, dan promosi membawa dampak positif dalam peningkatan motivasi tentang five moments hand hygiene. Sedangkan factor ekstrinsik seperti adanya role model dalam melakukan hand hygiene, oleh Ka. Unit, monitoring berkala dari bagian dari PPI dan fasilitas pendukung yang memadai juga mempengaruhi motivasi perawat.

Kepatuhan perawat melakukan five moments hand hygiene merupakan salah satu faktor yang mempunyai pengaruh besar terhadap kesehatan perawat dan pasien dalam pencegahan terjadiannya infeksi nosokomial. Ketidakpatuhan perawat dalam melakukan five moments hand hygiene dapat mengakibatkan bertambahnya penyakit dari infeksi nosokomial, memperpanjang jumlah hari rawat selama di rumah sakit hingga dapat menyebabkan kematian bagi pasien, dapat menularkan kepada orang lain setelah meninggalkan rumah sakit bagi pengunjung, menjadi barier (pembawa kuman) yang menularkan kepada pasien lain dan diri sendirir bagi perawat, menurunkan mutu pelayanan rumah sakit hingga pencabutan ijin operasional rumah sakit (Wawan \& Dewi, 2011).

Dalam penelitian ini, kepatuhan perawat melakukan five moments hand hygiene berhubungan dengan tingkat pengetahuan dan motivasi. Pada dasarnya pengetahuan yang baik akan menghasilkan perilaku yang positif (Prabawati \& Natalia, 2020), dalam penelitian ini adalah perilaku kepatuhan dan ketepatan melakukan five moments hand hygiene. Hasil penelitian ini juga didukung oleh penelitian dari Gea et al. (2018) yang menyatakan ada hubungan pengetahuan dan motivasi terhadap kepatuhan perawat dalam melakukan hand hygiene ( $p$ value < 0.05). Lebih lanjut dijelaskan bahwa variabel yang paling 
dominan mempengaruhi kepatuhan perawat dalam melakukan hand hygiene adalah motivasi, dengan odds rasio $\operatorname{Exp}$ (B) 2,487.

Dari penjelasan di table 2, terlihat bahwa responden perawat belum ada yang melakukan five moments hand hygiene secara 100\%. Hal ini dapat mengakibatkan pada gagalnya program patient safety; dimana five moments hand hygiene ini telah terbukti efektif untuk mencegah transmisi selama perawatan antara tenaga kesehatan dan pasien. Adapun moment terendah adalah sebelum kontak dengan pasien $(72.5 \%)$ diikuti dengan setelah kontak dengan pasien (85\%) dan sebelum melakukan tindakan Aseptik (87.5\%). Menurut WHO (2009) transmisi mikroorganisme yang dibawa perawat saat memasuki kamar atau akan kontak dengan pasien dapat berasal dari lingkungan sekitar perawat seperti furniture, dinding, pintu ataupun document yang sebelumnya disentuh perawat. Sedangkan, setelah kontak dengan pasien, perawat akan mudah terpapar dengan cairan tubuh pasien, tempat tidur, meja, linen, selang infus atau peralatan medis lain yang akan mengontaminasi perawat dan alat lain yang akan disentuh kemudian.

Hasil temuan ini sejalan juga dengan penelitian sebelumnya, dimana nilai rendah juga terjadi pada moment sebelum kontak dengan pasien (Shobowale, Adegunle \& Onyedibe, 2016; Susilo, 2015). Lebih lanjut (Shobowale, Adegunle \& Onyedibe, 2016) menjelaskan bahwa dari hasil observasi tenaga kesehatan tidak melakukan hand hygine pada moment sebelum melakukan tindakan invasive karena mereka langsung mengenakan sarung tangan lalu menghampiri pasien. Hal ini kurang disadari oleh perawat bahwa prosedur hand hygine adalah juga untuk menjaga kesehatan diri sendiri dan mencegah transmisi silang infeksi.

Berbagai alasan diungkapkan oleh perawat saat lalai melakukan five moments hand hygiene adalah karena tingginya beban kerja, keterbatasan waktu dan lupa karena banyaknya tugas yang harus dikerjakan. Mereka menyatakan tanggung jawab untuk merespon pasien dengan cepat menjadi prioritas utama, sehingga mayoritas perawat melakukan hand hygiene setelah selesai menangani kebutuhan pasien untuk mempersingkat waktu.

Beban kerja tenaga kesehatan terutama dalam menghadapi pasien dengan tingkat ketergantungan tinggi menjadi salah satu faktor yang dapat mempengaruhi tidakpatuhan perawat dalam pelaksanaan hand hygine. Hal ini didukung dari hasil studi kualitatif oleh Atif et al. (2019) bahwa salah satu factor yang mempengaruhi perawat dalam mencuci tangan adalah hambatan dalam organisasi, yang meliputi beban kerja yang berat dan jumlah staf yan tidak adekuat. Perawat menjelaskan bahwa keadaan menjadi lebih berat bila kapasitas pasien di unit terisi maksimal dan beragamnya kasus pasien yang dihadapi.

Selain beban kerja, factor fasilitas juga dapat menjadi hambatan perawat dalam 
melakukan kepatuhan melakukan five moments hand hygiene. Shobowale, Adegunle \& Onyedibe (2016) menemukan bahwa kurangnya wastafel dengan air mengalir dan ketiadaan alcohol hand lotions jua menjadi kendala. Hal ini dapat diatasi dengan menambah fasilitas seperti memperbanyak wastafel cuci tangan sehingga perawat tidak perlu menunggu/antri saat akan melakukan prosedur hand hygine.

\section{Simpulan Dan SARaN}

Berdasarkan hasil penelitian yang sudah dilakukan dapat disimpulkan bahwa:

a. Tingkat kepatuhan perawat melakukan five moments hand hygiene dipengaruhi oleh tingkat pengetahuan dan motivasi perawat. Semakin tinggi pengetahuan dan motivasi akan semakin patuh pula perawat melakukan five moments hand hygiene serta ketepatan hand hygiene ( $p$ value $<0.05$ )

b. Tingkat kepatuhan perawat dalam melakukan five moment hand hygiene belum sepenuhnya patuh karena dari setiap moment tidak ada yang dilakukan $100 \%$.

c. Perawat yang melakukan prosedur hand hygine belum tepat pelaksanaannya karena ada beberapa bagian yang belum dilaksanakan dengan benar.

Penelitian ini merekomendasikan agar sosialiasi dan simulasi prosedur hand hygine dapat dilakukan secara berkala bahkan perlu dilakukan lomba kebersihan tangan antar unit sehingga pengetahuan dan motivasi perawat untuk melakukan five moments hand hygiene semakin meningkat. Penambahan sarana dan prasarana seperti penambahan wastafel cuci tangan serta poster juga perlu dilengkapi sehingga meningkatkan kepatuhan dan ketepatan perawat melakukan hand hygine guna mencegah terjadinya transmisi mikroorganisme yang akan menyebabkan terjadinya infeksi nosokomial.

\section{DAFTAR PUSTAKA}

Atif, S., Lorcy, A., \& Dubé, E. (2019). Healthcare workers' attitudes toward hand hygiene practices: Results of a multicentre qualitative study in Quebec. Canadian Journal of Infection Control, 34(1), 41-48. https://doi.org/10.36584/cjic.2019.004

Gea, I. A. yanto, Fitriani, A. D., \& Theo, D. (2018). Faktor Kepatuhan Perawat Dalam Penerapan Hand Hygiene di Instalasi Rawat Inap RSUD Gunungsitoli. Jurnal Kesehatan Global, 1(3), 102. https://doi.org/10.33085/jkg.v1i3.3951

Khan, H. A., Baig, F. K., \& Mehboob, R. (2017). Nosocomial infections: Epidemiology, prevention, control and surveillance. Asian Pacific Journal of Tropical Biomedicine, 7(5), 478-482. https://doi.org/10.1016/j.apjtb.2017.01.0 19

Listiowati , E., \& Nilamsari, L. (2015). Efektivitas Pemberian Vitamin. Jurnal Medicoeticolegal Dan Manajemen Rumah Sakit, 4(1), 1-26. https://journal.umy.ac.id/index.php/mrs/a rticle/view/1112/1191

Mera, D., Andriani, Y., \& Gustinawati. (2018). Penerapan Cuci Tangan Five Momen Dengan Angka Kejadian Infeksi Nosokomial. Prosiding Seminar Kesehatan Perintis, 1(2), 8-16.

Prabawati, D. \& Natalia, L. (2020). the Effectiveness of Self-Care Model on Diabetes Self-. Indonesian Nursing Journal Of Education And Clinic (INJEC), 5(1), 1-7.

Sani, F. N., \& Pratiwi, M. R. (2017). the Corelation Between Nurse Motivation and the Compliance Level At Hand 
Washing. 14, 0-7.

Setiawan, Y. (2016). Universal Percaution. Faktor- Faktor Yang Berhubungan Dengan Kepatuhan Perawat Dalam Melakukan Cuci Tangan Sebelum Dan Setelah Tindakan Keperawatan Diruang Punica Rumah Sakit Sentra Medika Cisalak Depok. https://www.google.com/search?q=faktor +faktor+yang+berhubungan+dengan+per ilaku+mencuci+tangan+perawat\&ie $=$ utf$8 \&$ oe $=$ utf -8

Shobowale, E. O., Adegunle, B., \& Onyedibe, K. (2016). An assessment of hand hygiene practices of healthcare workers of a semi-urban teaching hospital using the five moments of hand hygiene. Nigerian Medical Journal: Journal of the Nigeria Medical Association, 57(3), 150-154.

https://doi.org/https://doi.org/10.4103/03 00-1652.184058

Sikora, A., Zahra, F. (2021). Nosocomial Infections. In: StatPearls [Internet]. Treasure Island (FL): StatPearls Publishing; Available from: Https://Www.Ncbi.Nlm.Nih.Gov/Books/N BK559312/.

Soedarto, S. (2016). Infeksi nosokomial di rumahsakit. hospital nosocomial infections (Issue January). Sagung Seto. https://www.researchgate.net/publication /310293816

Susilo, D. B. (2015). Kepatuhan Pelaksanaan Kegiatan Hand Hygiene Pada Tenaga Kesehatan Di Rumah Sakit X Surabaya. Dwi Bagus Susilo, 2(2), 200-204. https://ojs.iik.ac.id/index.php/wiyata/arti cle/view/61/61

Wawan, A. \& Dewi, M. (2011). Teori dan pengukuran pengetahuan sikap dan perilaku manusia: dilengkapi contoh kuesioner. Nuha Medika.

World Health Organization. (2009). " My Five Moments for Hand Hygiene" Concept (H. ur R. Malik (ed.)). https://www.who.int/gpsc/tools/Manual_ 5_moments_Pakistan.pdf?ua $=1$

World health organization (WHO). (2009). Hand hygiene technical reference manual: to be used by health-care workers, trainers and observers of hand hygiene practices. Geneva: WHO., 1-31. http://apps.who.int/iris/bitstream/10665/4 4196/1/9789241598606_eng.pdf\%5Cnht tp://whqlibdoc.who.int/publications/2009 /9789241598606_eng.pdf 